\title{
Thermal stability of purified superoxide dismutase from liver of commercially valuable fish, Labeo rohita Exposed to $\mathrm{Pb}+\mathrm{Cr}$ mixture
}

\author{
Huma Naz ${ }^{1, *}$, Sajid Abdullah², Tanveer Ahmed ${ }^{3 *}$, Khalid Abbas ${ }^{2}$, Muhammad Umar Ijaz ${ }^{2}$, Muhammad \\ Adeel Hassan ${ }^{4}$ and Muhammad Anjum $\mathrm{Zia}^{5}$ \\ ${ }^{1}$ Department of Zoology, Cholistan University of Veterinary and Animal Sciences, Bahawalpur, Pakistan; ${ }^{2}$ Department of \\ Zoology, Wildlife and Fisheries, University of Agriculture, Faisalabad, Pakistan; ${ }^{3}$ Department of Life Sciences, Khwaja \\ Fareed University of Engineering and Information Technology, Rahim Yar Khan, Pakistan; ${ }^{4}$ Department of Parasitology, \\ Cholistan University of Veterinary and Animal Sciences, Bahawalpur, Pakistan $;{ }^{5}$ Department of Chemistry and \\ Biochemistry, University of Agriculture, Faisalabad, Pakistan \\ *Corresponding author's e-mail: dr.humanaz98@gmail.com, tanvirahmeduaf@gmail.com
}

In this experiment, effect of lead $(\mathrm{Pb})+$ chromium $(\mathrm{Cr})$ mixture on superoxide dismutase (SOD) in the liver of Labeo rohita at a concentration of $11.1 \mathrm{mgL}^{-1}$ was observed. The ammonium sulphate precipitation and ion exchange chromatography techniques were successfully used to purify SOD. After purification, SOD activity of control and $\mathrm{Pb}+\mathrm{Cr}$ treated fish was noted as 581.00 and $645.45 \mathrm{UmL}^{-1}$, respectively while the specific activity was 1383.33 and $1613.62 \mathrm{Umg}^{-1}$, respectively. The fold purification value of SOD was 2.75 and 2.45 for control and stressed fish, respectively. The recovery was calculated as 77.06 and $57.43 \%$ for control and stressed fish, respectively. The results of kinetic characterization showed that SOD form control and exposed fish had maximum activity at $\mathrm{pH} 6.5$ and 7.0. Temperature also had a significant effect on activity of SOD. The SOD activity was measured maximum at $30^{\circ} \mathrm{C}$ for both control and $\mathrm{Pb}+\mathrm{Cr}$ exposed fish. The $\mathrm{K}_{\mathrm{m}}$ value of liver SOD for control and $\mathrm{Pb}+\mathrm{Cr}$ treated $L$. rohita was calculated as 1.48 and $0.62 \mathrm{mM}$, respectively. The value of $\mathrm{V}_{\max }$ for $\mathrm{SOD}$ from liver of control and $\mathrm{Pb}+\mathrm{Cr}$ exposed fish was 1000 and $570 \mathrm{U} \mathrm{mL}^{-1}$, respectively. The enthalpy of denaturation $\left(\Delta \mathrm{H}^{*}\right)$ for liver SOD from control and $\mathrm{Pb}+\mathrm{Cr}$ exposed $L$. rohita was computed as 3.492 and $2.802 \mathrm{KJ} \mathrm{mol}^{-1}$ at $40^{\circ} \mathrm{C}$, respectively and these values were dropped off with increasing the temperature until it remains 3.251 and $2.561 \mathrm{KJ} \mathrm{mol}^{-1}$ at $70^{\circ} \mathrm{C}$, respectively. The free energy of thermal denaturation $\left(\Delta \mathrm{G}^{\circ}\right)$ of liver SOD was slightly increased with increasing temperature until $75^{\circ} \mathrm{C}$ which shows its resistance against heat. The values of $\Delta \mathrm{G}^{\circ}$ was observed as 58.03 and $57.95 \mathrm{KJ} \mathrm{mol}^{-1}$ for control and exposed fish at $40^{\circ} \mathrm{C}$, respectively while the same was increased upto 62.37 and $62.00 \mathrm{KJ} \mathrm{mol}^{-1}$ at $70^{\circ} \mathrm{C}$, respectively. It was concluded from negative value of $\Delta \mathrm{S}^{*}$ (entropy of inactivation) that the SOD is stable thermodynamically.

Keywords: SOD, purification, characterization, heavy metals mixture, fish

\section{INTRODUCTION}

The pollution of freshwater bodies with a broad range of toxicants has become a hot issue all over the world. A major source of aquatic pollution includes industries, domestic and anthropogenic activities which released heavy metals in a large amount. These heavy metals may severely affect the ecological balance when they enter into the aquatic bodies (Aladesanmi, 2014). Heavy metals have ability to amass in the body of organism inhibited in aquatic bodies, which affects not only productivity and reproductive capabilities of the animals, but also human health that consume these organisms as a food source. Like, other animals, fish are an organism which cannot escape from injurious effects of these pollutants (Areola, 2007).

Lead $\left(\mathrm{Pb}^{+2}\right)$ is a prominent toxicant that has no important role in biological processes of life and may exert negative impacts upon long-term exposure (Mager, 2012). The mechanism of $\mathrm{Pb}$ induced toxicity is yet not clear, but it is evidenced that stimulate oxidative stress by forming the reactive oxygen species (ROS) (Dewanjee et al., 2013). Chromium (Cr) is also listed as a toxic and mutagenic element due to its ability to cross cell membrane and make complexes with intracellular macro-molecules such as genetic material (Venkatramreddy and Paul, 2011; Rahman et al., 2012).

Naz, H., S. Abdullah, T. Ahmed, K. Abbas, M.U. Ijaz, M.A. Hassan \& M.A. Zia.2021. Thermal stability of purified superoxide dismutase from liver of commercially valuable fish, Labeo rohita Exposed to Pb+Cr mixture. Pak. J. Agri. Sci. 58:1191-1196.

[Received 28 Oct 2019; Accepted 16- Sep 2021; Published (online) 21 Sep 2021] 
The ROS produced by heavy metals can cause the oxidation of macro-molecules like protein, lipids and RNA/DNA. Organisms have an efficient defensive mechanism of enzymes to reduce the injurious effects of ROS which includes superoxide dismutase (SOD), glutathione peroxidase (GPx), catalase (CAT) and reduced glutathione (GSH), and non-enzymatic vitamin E (Trenzado et al., 2006; Jankowiak et al., 2015). Many authors conducted the research on heavy metals induced biochemical alterations in both organs and blood of different species of fish (Rani, 2000). These biochemical parameters such as antioxidant enzymes are considered to be a very sensitive biomarker to evaluate the existence of pollutants before the detrimental effects appear in aquatic individuals (Gul et al., 2004; Cazenave et al., 2014). Temperature is one of abiotic factors that is not only limits the geographical distribution of living organisms but can also affect the biological processes (Windisch et al., 2011). Fish is a poikilotherm, its metabolic rate is related to environmental temperature (Clarke and Fraser, 2004), and so temperature is considered as a stressing factor for aquatic animals (Wedemeyer et al., 1990). Studies reveal that the thermal tolerance of an organism is closely related to its aerobic ability because both heating and cooling may disturb the oxygen balance in the organs, by stimulating the production of ROS. Keeping in view above mentioned $\mathrm{Cr}$ and $\mathrm{Pb}$ toxicity to fish, this study was conducted to evaluate the sublethal effects of metals mixture on liver superoxide dismutase of Labeo rohita.

\section{MATERIALS AND METHODS}

Experimental layout: Labeo rohita was used as an experimental fish. The trial was performed in Wet Laboratory at Fisheries Research Farms, UAF, Pakistan. Specimen was acclimatized to the laboratory environment for few days by maintaining the $12 \mathrm{hr}$ light and $12 \mathrm{hr}$ dark photoperiod. After 14 days, fish $(n=10)$ were shifted to 75 -liter glass aquaria for experimental trial. The stock solutions for experiment were prepared from pure chloride salts of lead $(\mathrm{Pb})$ and chromium (Cr). Fish were kept under sub-lethal concentration, $11.1 \mathrm{mg}$ $\mathrm{L}^{-1}$ of $\mathrm{Pb}+\mathrm{Cr}$ mixture $(1: 1$ ratio) calculated on the base of 96 h $\mathrm{LC}_{50}\left(33.11 \mathrm{mgL}^{-1}\right)$ which was computed by Batool and Javed (2015). Fish kept in clean water was used as control group. At the end of 14 days experiment, the fish were dissected and liver was collected from both control and $\mathrm{Pb}+\mathrm{Cr}$ mixture treated fish for superoxide dismutase (SOD) analyses at $-20^{\circ} \mathrm{C}$.

Extraction of SOD: The liver of fish was ground in phosphate buffer $(0.2 \mathrm{M}, \mathrm{pH} 6.5)$ added by the ration of $1: 4$ $\mathrm{w} / \mathrm{v}$. The homogenized material was centrifuged at 12,000 $\mathrm{rpm}$ and $4^{\circ} \mathrm{C}$ for $10 \mathrm{~min}$. After this, as result of centrifugation, supernatant was obtained, which was used for SOD assay.

Ammonium Sulphate Precipitation: The partial purification of extracted SOD was done by ammonium sulphate precipitation (Crapo et al., 1978). The precipitation was completed in two steps consist of salting in $(60 \%)$ and salting out $(80 \%)$. The obtained sample was desalted in phosphate buffer $(5 \mathrm{mM})$ of pH 7.8 containing EDTA $(0.01 \mathrm{mM})$.

Ion Exchange Chromatography: Partially purified SOD was completely purified by ion exchange chromatography (Zia et al., 2007). After every step of purification, the SOD activity (Giannopolitis and Ries, 1977) and total protein contents (Gornall et al., 1949) were also estimated.

Kinetic characterization: The optimum $\mathrm{pH}$ was noted by assaying the SOD at different $\mathrm{pH}(4.0-8.5)$. The optimum temperature was determined by assaying the SOD at different temperatures $\left(20-80^{\circ} \mathrm{C}\right)$ keeping the $\mathrm{pH}$ optimum for control and treated fish. The substrate specificity parameters viz. $K_{m}$ and $V_{\max }$ found out by assaying the SOD against various NBT (0.0-2.5 mM) concentrations (Leiter et al., 2004) by Lineweaver-Burk plot.

Thermodynamic characterization: The Ea for SOD was calculated from Arhennius plot (Obedunmi et al., 2006). Thermal denaturation was determined according to Zia et al. (2007). The thermodynamic parameters were calculated from the Eyring's absolute rate equation derived from the transition state theory of Eyring and Stearn (1939).

Data analysis: Following equations were used to analyze the data

(1) $\mathrm{Kd}=\left(\mathrm{k}_{\mathrm{b}} / \mathrm{h}\right) \mathrm{e}^{(\Delta \mathrm{H} / \mathrm{RT})} \cdot \mathrm{e}^{\left(\Delta \mathrm{S}^{*} / \mathrm{R}\right)}$

(2) $\Delta \mathrm{H}^{*}=\mathrm{Ea}^{*}-\mathrm{RT}$

(3) $\Delta \mathrm{G}^{*}=-\mathrm{RT} \ln \left\{\mathrm{K}_{\mathrm{d}}\left(\mathrm{h} / \mathrm{K}_{\mathrm{b}} . \mathrm{T}\right\}\right.$

(4) $\Delta \mathrm{S}^{*}=\left(\Delta \mathrm{H}^{*}-\Delta \mathrm{G}^{*}\right) / \mathrm{T}$

Where, $\mathrm{Kb}$ is Boltzman's constant $(\mathrm{R} / \mathrm{N}) 1.38 \times 10^{-23} \mathrm{JK}^{-1}, \mathrm{H}$ is Planck's constant $\left(6.63 \times 10^{-34} \mathrm{Js}\right), \mathrm{N}$ is Avogadro's No. $\left(6.02 \times 1023 \mathrm{ml}^{-1}\right), \mathrm{R}$ is Gas constant $\left(8.314 \mathrm{JK}^{-1} \mathrm{~mol}^{-1}\right), \Delta \mathrm{H}^{*}$ is Enthalpy of activation of denaturation, $\mathrm{T}$ is Absolute temperature, $\Delta \mathrm{G}^{*}$ is Free energy for denaturation, Ea* is the Activation energy for denaturation and $\Delta S^{*}$ is Entopy of activation of denaturation. Graphs were drawn in MS Excel and Slide write plus software.

\section{RESULTS}

SOD Purification: After purification, SOD activity of control and $\mathrm{Pb}+\mathrm{Cr}$ exposed fish was noted as 581.00 and 645.45 $\mathrm{UmL}^{-1}$, respectively while the specific activity was measured 1383.33 and $1613.62 \mathrm{U}$ (unit) $\mathrm{mg}^{-1}$, respectively. In control, $11^{\text {th }}$ fraction of ion-exchange chromatography had the highest activity of SOD while in exposed fish maximum activity noted at $18^{\text {th }}$ fraction (Fig. 1). The fold purification value of SOD was calculated as 2.75 and 2.45 for control and stressed fish, respectively. The recovery was calculated as 77.06 and $57.43 \%$ for control and stressed fish, respectively (Table 1). The total protein in liver of treated fish decreased in comparison to control and it was decreased at each step of purification. 
Table 1. Purification of SOD from liver of $L$. rohita

\begin{tabular}{|c|c|c|c|c|c|c|c|c|c|c|}
\hline \multirow[t]{2}{*}{ Purification Steps } & \multicolumn{2}{|c|}{$\begin{array}{l}\text { Activity } \\
\left(\text { UmL }^{-1}\right)\end{array}$} & \multicolumn{2}{|c|}{$\begin{array}{c}\text { Specific Activity } \\
\left(\mathbf{U} \mathrm{mg}^{-1}\right)\end{array}$} & \multicolumn{2}{|c|}{$\begin{array}{c}\text { Protein } \\
\left(\mathrm{mg} \mathrm{mL}^{-1}\right)\end{array}$} & \multicolumn{2}{|c|}{ Fold purification } & \multicolumn{2}{|c|}{ \% age yield } \\
\hline & Control & $\mathrm{Pb}+\mathrm{Cr}$ & Control & $\mathrm{Pb}+\mathrm{Cr}$ & Control & $\mathrm{Pb}+\mathrm{Cr}$ & Control & $\mathrm{Pb}+\mathrm{Cr}$ & Control & $\mathrm{Pb}+\mathrm{Cr}$ \\
\hline Crude & 754.00 & 809.00 & 502.66 & 657.72 & 1.50 & 1.23 & 1.00 & 1.00 & 100.0 & 100.0 \\
\hline SaltingIn $(60 \%)$ & 627.00 & 718.00 & 696.66 & 725.25 & 0.90 & 0.99 & 1.38 & 0.95 & 83.15 & 88.75 \\
\hline SaltingOut (80\%) & 609.09 & 672.00 & 801.43 & 840.00 & 0.76 & 0.80 & 1.59 & 1.32 & 80.78 & 83.06 \\
\hline Desalting & 595.00 & 650.00 & 991.00 & 1015.6 & 0.60 & 0.64 & 1.97 & 1.47 & 78.91 & 80.34 \\
\hline DEAE-Cellulose & 581.00 & 645.45 & 1383.3 & 1613.6 & 0.42 & 0.40 & 2.75 & 2.45 & 77.06 & 57.43 \\
\hline
\end{tabular}

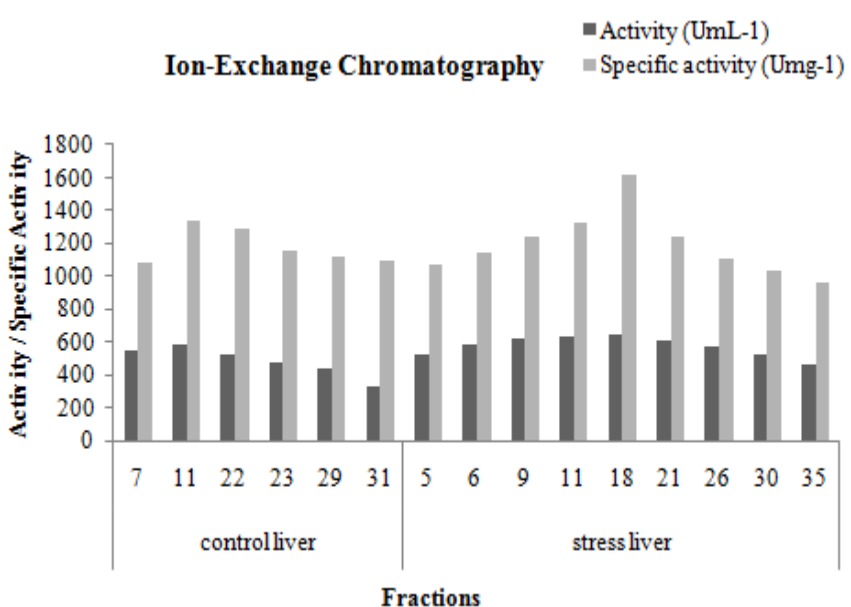

Figure 1. Fractional details of liver SOD by Ion Exchange Chromatography

\section{Kinetic Characterization of SOD}

Optimum pH and Temperature: The results of kinetic characterization showed that SOD from control and exposed fish had higher activity at $\mathrm{pH} 6.5$ and 7.0 (Fig. 2). Temperature also had a significant effect on activity of SOD. The SOD activity was maximum at $30^{\circ} \mathrm{C}$ for both control and $\mathrm{Pb}+\mathrm{Cr}$ exposed fish. It was noted that SOD activity was accelerated upto a certain limit after that it was decreased (Fig. 3).

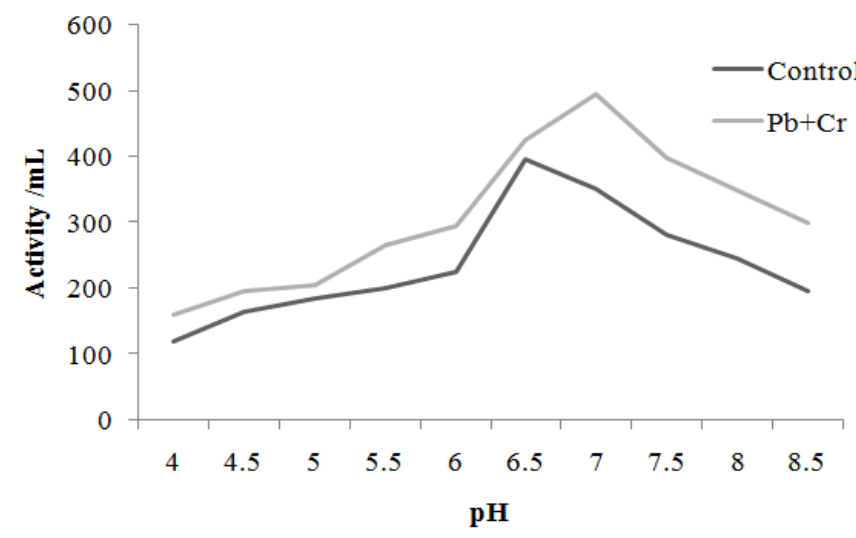

Figure 2. Alteration induced in liver SOD activity of $L$. rohita by pH

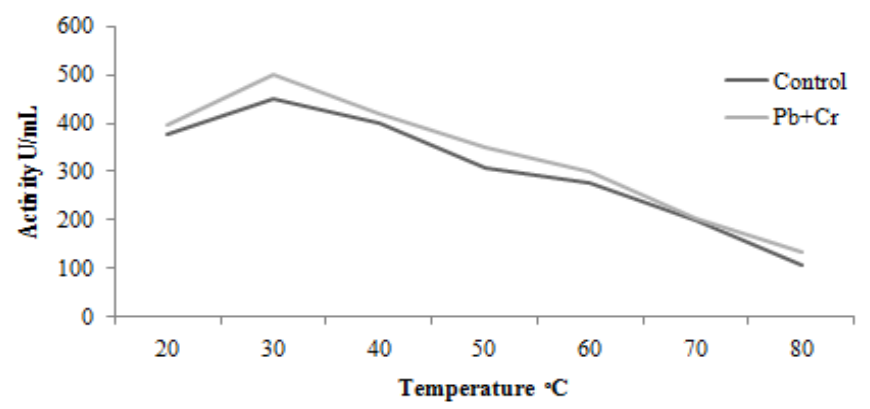

Figure 3. Alteration induced in liver SOD activity of $L$. rohita by temperature

Substrate Specificity: The lower $\mathrm{K}_{\mathrm{m}}$ value for liver SOD of fish showed its high affinity for NBT. The $\mathrm{K}_{\mathrm{m}}$ value of SOD for the liver of control and treated fish was calculated as 1.48 and $0.62 \mathrm{mM}$, respectively. The value of $\mathrm{V}_{\max }$ for SOD from liver of control and $\mathrm{Pb}+\mathrm{Cr}$ exposed fish was 1000 and $570 \mathrm{U}$ $\mathrm{mL}^{-1}$, respectively (Fig. 4).
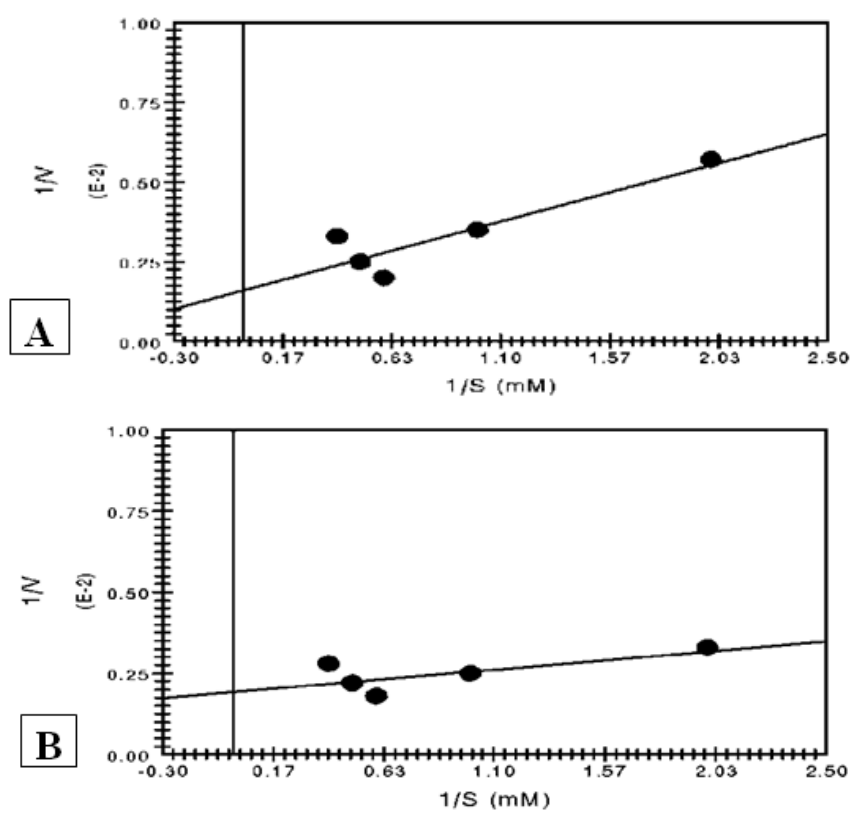

Figure 4. Impact of NBT concentration on liver SOD activity of control (A) and $\mathrm{Pb}+\mathrm{Cr}(\mathrm{B})$ exposed $L$. rohita 
Table 2. Calculations for thermal denaturation of SOD from liver of $\mathrm{Pb}+\mathrm{Cr}$ exposed $L$. rohita

\begin{tabular}{|c|c|c|c|c|c|c|c|c|c|c|}
\hline \multirow{2}{*}{$\begin{array}{l}\text { Temp. } \\
\text { (K) }\end{array}$} & \multicolumn{2}{|c|}{$K_{d}\left(\min ^{-1)}\right.$} & \multicolumn{2}{|c|}{$\mathbf{T}_{1 / 2}(\min )$} & \multicolumn{2}{|c|}{$\Delta \mathrm{H}^{*}\left(\mathrm{KJ} \mathrm{mol}^{-1}\right)$} & \multicolumn{2}{|c|}{$\Delta G^{*}\left(K^{\prime} ~ m o l^{-1}\right)$} & \multicolumn{2}{|c|}{$\Delta \mathrm{S}^{*}\left(\mathrm{JK}^{-1} \mathrm{~mol}^{-1}\right)$} \\
\hline & CL & $\mathrm{Pb}+\mathrm{Cr}$ & $\mathbf{C L}$ & $\mathrm{Pb}+\mathrm{Cr}$ & $\mathbf{C L}$ & $\mathrm{Pb}+\mathrm{Cr}$ & CL & $\mathrm{Pb}+\mathrm{Cr}$ & CL & $\mathrm{Pb}+\mathrm{Cr}$ \\
\hline 313 & 0.0146 & 0.0154 & 47.79 & 45.00 & 3.492 & 2.802 & 58.033 & 57.958 & -0.174 & -0.176 \\
\hline 318 & 0.0175 & 0.0181 & 39.60 & 38.28 & 3.454 & 2.764 & 58.310 & 58.252 & -0.173 & -0.174 \\
\hline 323 & 0.0185 & 0.0186 & 37.45 & 37.25 & 3.409 & 2.719 & 59.117 & 59.102 & -0.172 & -0.175 \\
\hline 328 & 0.0188 & 0.0199 & 36.86 & 34.22 & 3.368 & 2.678 & 59.934 & 59.779 & -0.172 & -0.174 \\
\hline 332 & 0.0189 & 0.0215 & 36.66 & 32.32 & 3.334 & 2.644 & 60.633 & 60.277 & -0.173 & -0.173 \\
\hline 337 & 0.0189 & 0.0215 & 36.66 & 32.34 & 3.293 & 2.603 & 61.492 & 61.131 & -0.173 & -0.174 \\
\hline 342 & 0.0189 & 0.0215 & 36.66 & 32.34 & 3.251 & 2.561 & 62.372 & 62.006 & -0.173 & -0.174 \\
\hline
\end{tabular}

$\mathrm{Ea}=$ Control $=6.094 \mathrm{~kJ} / \mathrm{mol}, \mathrm{Pb}+\mathrm{Cr}=5.404 \mathrm{~kJ} / \mathrm{mol}$ calculated from Figure 6 and 7

Thermodynamic Characterization: The activity of SOD was greatly affected by changing temperature. To see the stability changes in SOD activity against different temperature 20 $80^{\circ} \mathrm{C}$ the activation energy for thermal denaturation $(\mathrm{Ea})$ was derived from Arrhenius plot which showed a decline in SOD activity also indicates that half-life of SOD from liver of fish was also decreased with an increase in temperature (Fig. 5). The Ea for liver SOD from control and exposed fish was calculated as 6.094 and $5.404 \mathrm{~kJ} / \mathrm{mol}$.
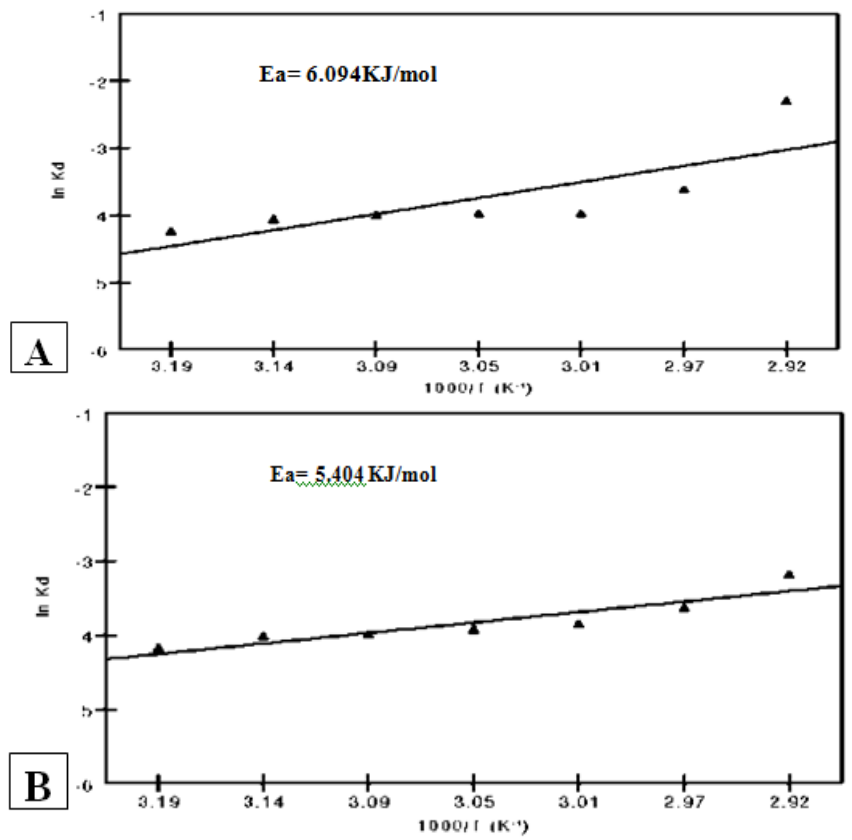

Figure 5. Arrhenius plot of irreversible thermal denaturation of liver SOD from control (A) and $\mathrm{Pb}+\mathrm{Cr}$ (B) exposed L. rohita.

Pseduo-first order plot showed the irreversible thermal inactivation of liver SOD at different temperatures (Fig. 6). The enthalpy of denaturation $\left(\Delta \mathrm{H}^{*}\right)$ for liver SOD from control and $\mathrm{Pb}+\mathrm{Cr}$ exposed $L$. rohita were computed as 3.492 and $2.802 \mathrm{KJ} \mathrm{mol}^{-1}$ at $40^{\circ} \mathrm{C}$, respectively and these values were dropped off with increasing temperature until it remains 3.251 and $2.561 \mathrm{KJ} \mathrm{mol}^{-1}$ at $70^{\circ} \mathrm{C}$, respectively. The free energy of thermal denaturation $\left(\Delta \mathrm{G}^{\mathrm{o}}\right)$ of liver SOD was slightly increased with increasing temperature until $75{ }^{\circ} \mathrm{C}$ which shows its resistance against heat. The values of $\Delta \mathrm{G}^{\circ}$ were observed as 58.03 and $57.95 \mathrm{KJ} \mathrm{mol}^{-}$for control and exposed fish at $40{ }^{\circ} \mathrm{C}$, respectively while the same was increased upto 62.37 and $62.00 \mathrm{KJ} \mathrm{mol}^{-1}$ at $70^{\circ} \mathrm{C}$, respectively. It was concluded from the negative value of $\Delta \mathrm{S}^{*}$ (entropy of inactivation) that the SOD is stable thermodynamically (Table 2).

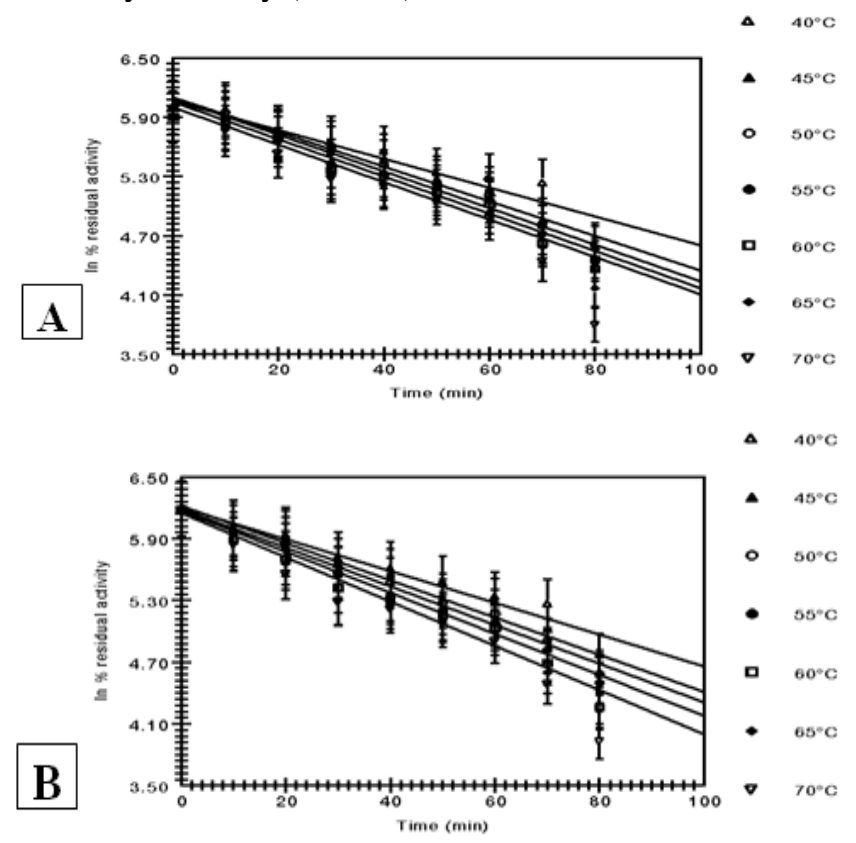

Figure 6. Pseduo-first order plot of irreversible thermal inactivation of liver SOD from control (A) and $\mathrm{Pb}+\mathrm{Cr}$ (B) exposed L. rohita

\section{DISCUSSION}

In the present research work, $\mathrm{Pb}+\mathrm{Cr}$ mixture significantly accelerated the activity of SOD in liver of $L$. rohita in comparison to control. Similarly, Velma and Tchounwon (2010) determined the chromium-induced stimulation in liver of Carassius auratus. Hexavalent chromium significantly 
increases the SOD activity in liver of $L$. rohita under laboratory condition (Kumari et al., 2014). The SOD level was accelerated upto $61 \%$ in liver of Clarias gariepinus under metals stress (Farombi et al., 2007). According to Basha and Rani (2003) the SOD level in liver of Oreochromis mossambicus was increased significantly under sub-lethal dose of cadmium chloride. Messaoudi et al. (2009) noted the accelerated level of SOD in liver of Salaria basilisca exposed to cadmium for 2 and 4 weeks.

In the present research, the specific activity of SOD increased at every step of purification. Similarly, Naz et al. (2019) also noted the increased specific activity at every step. The specific activity for control and $\mathrm{Pb}+\mathrm{Cr}$ exposed fish was calculated as1750.13 and $1272.72 \mathrm{Umg}^{-1}$ in the kidney of $L$. rohita, respectively. Rafique et al. (2018) calculated the purified SOD activity as 508.33 and $427 \mathrm{UmL}^{-1}$ from kidney of control and $\mathrm{Pb}+\mathrm{Cr}$ treated fish while the specific activity was noted as 1105.06 and $1055.55 \mathrm{Umg}^{-1}$, respectively. Ken et al. (2003) also calculated the specific activity of purified $\mathrm{Cu} / \mathrm{Zn} \mathrm{SOD}$ as $2000 \mathrm{Umg}^{-1}$ from zebra fish. The purified $\mathrm{Cu} / \mathrm{ZnSOD}$ from the muscle of black porgy had a specific activity of $3318 \mathrm{U} \mathrm{mg}^{-1}$ (Lin et al., 2001).

In this work, the fold purification value of SOD was calculated as 2.75 and 2.45 for control and stressed fish, respectively. The yield recovery was calculated as 77.06 and $57.43 \%$ for control and stressed fish, respectively. Naz et al. (2019) reported that the kidney SOD from control and $\mathrm{Pb}+\mathrm{Cr}$ treated L. rohita was 2.52 and 2.68-fold purified with \%age recovery of 72.13 and 58.73, respectively. Rafique et al. (2018) noted the fold purification of SOD as 1.98 and 2.70 with $70 \%$ and $68 \%$ recovery for control and $\mathrm{Pb}+\mathrm{Cr}$ treated fish, respectively.

In present work, kinetic characterization results showed that SOD form control and exposed fish had maximum activity at pH 6.5 and 7.0. According to Rafique et al. (2018) at pH 7.0 and 7.5 maximum activity of SOD of control and stress fish was observed while the temperature was $40^{\circ} \mathrm{C}$. The purified $\mathrm{Cu} / \mathrm{Zn}$ SOD was thermally stable at $70^{\circ} \mathrm{C}$ when heated for 10 mints (Ken et al., 2003). In thermal stability test, the higher SOD activity from blackporgy was noted at $\mathrm{pH} 2.0$ and 3.0 as 11.3 and $24.2 \%$ when the range was 5.8-11.2 (Lin et al., 2001). Lin et al. (2001) also calculated the thermal inactivation constant rate of SOD from black porgy was $0.0237 \mathrm{~min}^{-1}$ and half-life was $27.8 \mathrm{~min}^{-1}$ at $80^{\circ} \mathrm{C}$. Naz et al. (2019) noted the maximum activity of SOD at pH 7.5 and 30 ${ }^{\circ} \mathrm{C}$ from the kidney of $\mathrm{Pb}+\mathrm{Cr}$ exposed $L$. rohita. The thermal inactivation rate of SOD was $0.0171 \mathrm{~min}^{-1}$ and half-life was $40.52 \mathrm{~min}^{-1}$. The total protein in liver of exposed L. rohita decreased as compared to control and it was also decreased at every step of purification. Mohanty et al. (2013) reported the $32.17 \%$ reduction in total protein contents of $L$. rohita under chronic metal's stress. Significantly lower protein contents in liver of fish under toxicants exposure was also noted by Tufail et al. (2019).
Conclusion: In this research, exposure of $\mathrm{Pb}+\mathrm{Cr}$ mixture triggers the induction of reactive oxygen species and cause acceleration in SOD activity of Labeo rohita. An increased level of SOD plays a crucial role in the toxicity of metals. The finding of this research also emphasizes that the biochemical parameters are useful biomarker for understanding the heavy metals toxicity in aquatic ecosystem. Moreover, ammonium sulphate precipitation and column chromatography are very simple and convenient techniques to purify the SOD.

\section{REFERENCES}

Aladesanmi, O.T. 2014. Environmental characteristics and activities of antioxidant enzymes in African catfish Clarias gariepinus (Buchell) from selected fish ponds and inflow streams in Osun State [Masters thesis]. [Ife, Nigeria]: Institute of Ecology and Environmental Studies, Obafemi Awolowo University.

Areola, F.O. 2007. Fish marketing and export potentials of fish and fisheries products in Nigeria. In: Educative and Informative Aqua-cultural Workshop and Exhibitions Tagged: Sustainable fisheries livelihood: Management and food security in Nigeria; 2007 Feb 23; Lagos, Nigeria. Ibadan, Nigeria: University of Ibadan, pp. 23.

Basha, P.S. and A.U. Rani. 2003. Cadmium-induced antioxidant defense mechanism in freshwater teleost Oreochromis mossambicus (Tilapia). Ecotoxicol. Environ. Saf. 56:218-221.

Batool, U. and M. Javed. 2015. Synergistic effects of metals (cobalt, chromium and lead) in binary and tertiary mixture forms on Catla catla, Cirrhina mrigala and Labeo rohita. Pak. J. Zool. 47:617-623.

Cazenave, J., C. Bacchetta, A. Rossi, A. Ale, M. Campana and M.J. Parma. 2014. Deleterious effects of wastewater on the health status of fish: a field caging study. Ecol. Indic. 38:104-112.

Crapo, J.D., J.M. Mccord and I. Fridovich. 1978. Preparation and assay of superoxide dismutases. Methods Enzymol. 53:382-393.

Clarke, A. and K.P.P. Fraser. 2004. Why does metabolism scale with temperature? Funct. Ecol. 18:243-251.

Dewanjee, S., R. Sahu, S. Karmakar and M. Gangopadhyay. 2013. Toxic effects of lead exposure in Wistar rats: Involvement of oxidative stress and the beneficial role of edible jute (Corchorus olitorius) leaves. Food. Chem. Toxicol. 55:78-91.

Erying, H. and A.E. Stearn. 1939. The application of the theory of absolute reaction rates to protein. Chem. Rev. 24:253-270.

Farombi, E.O., O.A. Adelowo and Y.R. Ajimoko. 2007. Biomarkers of oxidative stress and heavy metal levels as indicators of environmental pollution in African cat fish (Clarias gariepinus) from Nigeria Ogun River. Int. J. Environ. Res. Public Health. 4:158-165. 
Giannopolitis, C.N. and S.K. Ries. 1977. Superoxide dismutase occurrence in higher plants. Plant. Physiol. 59:309-314.

Goranll, A.G., C.J. Bardwill and M.M. David. 1949. Determination of serum protein by means of biuret reagent. J. biol. Chem. 177:751-766.

Gul, S., E. Belge-Kurutas, E. Y1ld1z, A. Sahan and F. Doran. 2004. Pollution correlated modifications of liver antioxidant systems and histopathology of fish (Cyprinidae) living in Seyhan Dam Lake, Turkey. Environ. Int. 30:605-609.

Jankowiak, D., R. Pilarczyk, R. Drozd, B. Pilarczyk, A. Tomza-Marciniak, G. Wysocka, I. Rzad, A. Drozd and J. Kuba. 2015. Activity of antioxidant enzymes in the liver of wild boars (Sus scrofa) from a selenium-deficient area depending on sex, age, and season of the year. Turk. J. Biol. 39: 129-138.

Ken, C.F., C.T. Lin, J.F. Shaw and J.L. Wu. 2003. Characterization of fish $\mathrm{Cu} / \mathrm{Zn}$-superoxide dismutase and its protection from oxidative stress. Mar. Biotechnol. 5:167-73.

Kumari, K., A. Khare and S. Dange. 2014. The applicability of oxidative stress biomarkers in assessing chromium induced toxicity in the fish Labeo rohita. Biomed. Res. Int. 2014:1-11.

Leiter, E., F. Marx, T. Pusztahelyi, H. Haas and I. Pocsi. 2004. Penicillium chrysogenum glucose oxidase: A study on its anti-fungal effects. J. Appl. Microbiol. 97:1201-1209.

Lin, C.T., T.L. Lee, K.J. Duan and J.C. Su. 2001. Purification and characterization of black porgy muscle $\mathrm{Cu} / \mathrm{Zn}$ superoxide dismutase. Zool. Stud. 40:84-90.

Mager, E. 2012. Lead. In: Wood CM, Farrell AP, Brauner CJ, Editors. Homeostasis and Toxicology of Non-Essential Metals. New York, NY, USA: Academic Press, pp 185236.

Messaoudi, I., S. Barhoumi, K. Said and A. Kerken. 2009. Study on the sensitivity to cadmium of marine fish Salariabasilisca (Pisces: Blennidae). J. Environ. Sci. 21: 1620-1624.

Mohanty, B.P., M.R. Mahananda and S. Pradhan. 2013. Cadmium induced toxicity and antioxidant activities in Labeo rohita (Hamilton). Environ. Ecol. Res., 1: 41-47.

Naz, H., S. Abdullah, K. Abbas and M.A. Zia. 2019. Thermodynamic characterization of kidney superoxide dismutase from Labeo rohita exposed to the mixture of lead and chromium. Pak. J. Zool. 51: 1105-1112.

Odebunmi, E.O., S.A. Iwarere and S.O. Owalude. 2006. Kinetics of oxidation of fructose, sucrose, and maltose by potassium permanganate in $\mathrm{NaHCO}_{3} / \mathrm{NaOH}$ buffer and Iridium (IV) complex in sodium acetate/acetic acid buffer. Inter. J. Chem. 16: 167-176.

Rafique, A., S. Abdullah, K. Abbas, K., H. Naz, and W. Hassan. 2018. Purification and partial characterization of superoxide dismutase from kidney of Hypophthalmichthys molitrix under exposure of metals mixture. Pakistan J. Zool. 50: 831-836.

Rahman, M.S., A.H. Molla, N. Saha and A., Rahman. 2012. Study on heavy metals levels and its risk assessment in some edible fishes from Bangshi River, Savar, Dhaka, Bangladesh. Food Chem. 134: 1847-1854.

Rani, A.U. 2000. Cadmium-induced bioaccumulation in the selected tissues of freshwater teleost, Oreochromis mossambicus (Tilapia). Ann New Yark Acad. Sci. 919:318-320.

Trenzado, C., M.C. Hidalgo, M.G. Gallego, A.E. Morales and M. Furne. 2006. Antioxidant enzymes and lipid peroxidation in sturgeon Acipenser naccarii and trout Oncorhynchus mykiss, A comparative study. Aquaculture. 254:758-767.

Tufail, F., S. Abdullah, H. Naz, K. Abbas and L. Shafique. 2019. Purification and kinetic characterization of hepatic catalase from carnivore fish, Channa striata exposed to agrochemicals (endosulfan+deltamethrin). Punjab Uni. J. Zool. 34:79-84.

Velma, V. and P.B. Tchounwou. 2010. Chromium-induced biochemical, genotoxic and histopathologic effects in liver and kidney of goldfish, carassius auratus. Mutat. Res. 698: 43-51.

Venkatramreddy, V. and B.T. Paul. 2011. Hexavalent chromium induced multiple biomarker responses in liver and kidney of gold fish, Carassius auratus. Environ. Toxicol. 26: 649-656.

Wedemeyer, G.A. B.A. Barton and D.J. McLeay (1990). Stress and acclimation. In: Schreck CB, Moyle PB (eds) Methods for fish biology. American Fisheries Society, Bethesda, Pp. 451-489.

Windisch, S.H., R. Kathover, H.O. Portner, S. Frickenhaus and M. Lucassen. 2011. Thermal acclimation in Antarctic fish: Transcriptomic profiling of metabolic pathways. Am. J. Physiol. Regul. Integr. Comp. Physiol. 301:14531466.

Zia, M.A., K. Rahman, M.K. Saeed and F. Anjum. 2007. Thermal characterization of hyperproduced glucose oxidase from Aspergillus niger BCG-5 mutant strain. ICME.Pp: 1950-1955. 